\title{
Genistein inhibits pro-inflammatory cytokines in human mast cell activation through the inhibition of the ERK pathway
}

\author{
DONG HWAN KIM ${ }^{1 *}$, WOO-SUNG JUNG ${ }^{2 *}$, MI EUN KIM ${ }^{1}$, HEE-WOO LEE ${ }^{2}$, HWA-YOUNG YOUN ${ }^{2}$, \\ JONG KEUN SEON ${ }^{3}$, HAENG-NAM LEE ${ }^{4}$ and JUN SIK LEE ${ }^{1}$ \\ ${ }^{1}$ Department of Biology, Immunology Research Lab, BK21-Plus Research Team for Bioactive Control Technology, \\ College of Natural Sciences, Chosun University, Gwangju 501-759; ${ }^{2}$ Department of Veterinary Internal Medicine, \\ College of Veterinary Medicine, Seoul National University, Seoul 151-742; ${ }^{3}$ Center for Joint Disease, \\ Chonnam National University Hwasun Hospital, Hwasun-eup, Hwasun-gun, Jeollanam-do 519-809; \\ ${ }^{4}$ Department of Mechanical Engineering, College of Engineering, Chosun University, \\ Gwangju 501-759, Republic of Korea
}

Received April 8, 2014; Accepted September 22, 2014

DOI: $10.3892 /$ ijmm.2014.1956

\begin{abstract}
Anaphylaxis is a rapidly occurring allergic reaction to any foreign substance, including venom from insects, foods and medications, which may cause fatalities. To prevent anaphylaxis, these triggers must be avoided. However, avoidance of numerous triggers is difficult. For this reason, the development of immunotherapeutic adjuvants that suppress the allergic response is important for anaphylaxis control. Mast cells are one of the major inflammatory cells involved in the inflammatory response, which secrete several inflammatory cytokines, including tumor necrosis factor (TNF)- $\alpha$, interleukin (IL)-6, and IL-1 $\beta$, and recruits other immune cells. Mast cells are also involved in a number of diseases, such as sinusitis, rheumatoid arthritis and asthma. Genistein, a phytoestrogen, has been reported to have anti-oxidative and anti-inflammatory activities. However, the effects of genistein on the anti-inflammatory response of mast cells remain unknown. In the present study, the anti-inflammatory effects of genistein on mast cells were investigated. Genistein significantly decreased IL-6 and IL-1 $\beta$ mRNA levels, as well as IL-6 production in PMA/A23187-induced mast cells activation.
\end{abstract}

Correspondence to: Professor Jun Sik Lee, Department of Biology, Immunology Research Lab, BK21-Plus Research Team for Bioactive Control Technology, College of Natural Sciences, Chosun University, 375 Seosuk-dong, Dong-gu, Gwangju 501-759, Republic of Korea E-mail: junsiklee@chosun.ac.kr

Professor Haeng-Nam Lee, Department of Mechanical Engineering, College of Engineering, Chosun University, 375 Seosuk-dong, Dong-gu, Gwangju 501-759, Republic of Korea

E-mail: hnalee@chosun.ac.kr

*Contributed equally

Key words: allergy, anaphylaxis, cytokines, genistein, mast cells
In addition, genistein inhibited the phosphorylation of ERK 1/2 in PMA/A23187-induced mast cell activation. However, phosphorylation of p38 was not altered. Thus, these findings indicate that genistein inhibited the inflammatory status of mast cells through inhibition of the ERK pathway.

\section{Introduction}

Allergic responses frequently occur in developed nations, with anaphylactic shock being particularly fatal (1). Anaphylactic shock is a rapidly occurring, severe allergic response that may cause mortality (2). Anaphylaxis can occur in response to any foreign substance, including venom from insects, foods and medications (3-5). Globally, 0.05-2\% of people are estimated to suffer anaphylaxis during their lifetime and this rate appears to be increasing (6). Avoiding the specific triggers, such as foods and medications, is critically imporant to prevent anaphylaxis (7). However, this is not always possible. Thus, development of immunoadjuvants is essential for preventing anaphylaxis and allergic reactions.

Mast cells derived from hematopoietic cells are associated with tissue immunity and innate immunity and play an significant role in allergic and anaphylactic reactions (1). Mast cells can secrete pre-formed mediators, including histamine, heparin and inflammatory cytokines, by degranulation $(8,9)$. Antigen immunoglobulin E ( IgE)-dependent-activated mast cells induce degranulation to secrete three types of mediators. Several inflammatory and chemotactic cytokines, such as interleukin (IL)-1 $\beta$, IL-6 and tumor necrosis factor (TNF)- $\alpha$, are produced from activated mast cells (10). Additionally, these pro-inflammatory cytokines support the well-recognized role of mast cells in allergic inflammation and hypersensitivity (10). Histamine release from mast cells stimulates cardiac contraction, vascular permeability and anaphylaxis; the IgE-dependent pathway, which results in histamine release, is part of the mechanism associated with anaphylaxis (1).

The production of these cytokines is transmitted through signal molecules, such as the transcription factors 
mitogen-activated protein kinase (MAPK) and nuclear factor

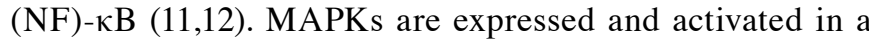
systemic inflammatory disorder and play an important role in the control of cytokines, chemokines and cell proliferation (13). As transcriptional factors, MAPK and NF- $\mathrm{kB}$ play a pivotal role in inflammation by virtue of their ability to induce transcription of an array of inflammatory genes, particularly the regulation of pro-inflammatory molecules, including IL-1 $\beta$, IL- 6 and TNF- $\alpha(14,15)$.

The phytoestrogen genistein (4',5,7-trihydroxyisoflavone) is an isoflavonoid compound containing soy beans. Genistein has a variety of biological effects, including anti-inflammatory and antioxidant properties, and inhibits protein tyrosine kinases (PTK) and influences immune responses $(16,17)$. Genistein also modulates the activation of NF- $\mathrm{kB}$ and Akt during inflammation (18). Immortalized human mammary epithelial cells demonstrated decreased extracellular signal-regulated kinase (ERK)1/ERK2 phosphorylation when treated with genistein, specifically inhibiting cytokine-induced ERK phosphorylation (19). Several animal studies indicate that genistein reduces production of pro-inflammatory molecules, such as IL-6 and TNF- $\alpha$, in rat plasma. In addition, in an acute liver inflammation model, oral administration of soy-derived genistein suppresses IL-6, IL-1 $\beta$ and TNF- $\alpha$ in RAW264.7 macrophages $(20,21)$. However, the signaling pathways involved in the anti-inflammatory effect of genistein on human mast cell activation remain unknown.

The aim of the present study was to investigate the anti-inflammatory effects of genistein on phorbol 12-myristate 13-acetate (PMA)- and A23187-, a calcium ionophore, induced expression of pro-inflammatory cytokines and histamine release, as well as their associated regulatory signaling pathways.

\section{Materials and methods}

Cell culture and genistein treatment. The human leukemic mast cell (HMC)-1 line was obtained from Dr Dae Ki Kim at Chunbuk National University (Jeonju-si, Korea). HMC-1 were cultured in Iscove's modified Dulbecco's medium (IMDM) supplemented with $10 \%$ heat-inactivated fetal bovine serum, $100 \mathrm{IU} / \mathrm{ml}$ penicillin, and $100 \mu \mathrm{g} / \mathrm{ml}$ streptomycin (PAA Laboratories Inc., Piscataway, NJ, USA) at $37^{\circ} \mathrm{C}$ and $5 \%$ $\mathrm{CO}_{2}$. Genistein was dissolved in dimethyl sulfoxide (DMSO) (Sigma, St. Louis, MO, USA) and diluted to the desired concentration in IMDM (final DMSO concentration $0.1 \% \mathrm{v} / \mathrm{v}$ ). An equal amount of DMSO was added to the control samples (medium only).

Cell viability. Cell viability was measured by the 3-[4,5-dimethylthiazol-2-yl]-2,5 diphenyl tetrazolium bromide (MTT) assay. HMC-1 $\left(2 \times 10^{4}\right.$ cells/well) were seeded in 96-well U-bottom culture plates with IMDM and incubated at $37^{\circ} \mathrm{C}$ and $5 \% \mathrm{CO}_{2}$. Cells were treated with various concentrations of genistein $(12.5-50 \mu \mathrm{mol} / \mathrm{ml})$ and incubated at $37^{\circ} \mathrm{C}$ for $24 \mathrm{~h}$. Following treatment, MTT $(0.5 \mathrm{mg} / \mathrm{ml})$ in medium was added to each well and cells were incubated at $37^{\circ} \mathrm{C}$ for $4 \mathrm{~h}$. Following incubation, the MTT solution was removed and the formazan product was dissolved in a solvent (DMSO:ethanol $=1: 1$ ) generating a colored solution. Absorbance was measured by an enzyme-linked immunosorbent assay (ELISA) microplate reader at a wavelength of $570 \mathrm{~nm}$ (BioTek, Winooski, VT, USA).

$R N A$ isolation and reverse transcription PCR (RT-PCR). Total RNA was isolated from genistein-treated cells using TRI reagent (Sigma) according to the manufacturer's instructions. To synthesize cDNA, $0.5 \mu \mathrm{g}$ of total RNA was primed with oligo(dT) and reacted with a mixture of Moloney murine leukemia virus reverse transcriptase (M-MLV reverse transcriptase), dNTP and reaction buffer (Promega, Madison, WI, USA). The mRNA levels of inflammatory cytokines were measured using synthetic cDNA and selective primers for PCR: $I L-6$ forward, GAG GCA CTG GCA GAA AAC AA; and reverse, TTG GGT CAG GGG TGG TTA TT; $I L-1 \beta$ forward, GTA CCT GAG CTC GCC AGT GA; and reverse, TGA AGC CCT TGC TGT AGT GG; $T N F-\alpha$ forward, CCA TCA GAG GGC CTG TAC CT; and reverse, CAG ACT CGG CAA AGT CGA GA; GAPDH forward, AAG GGT CAT CAT CTC TGC CC; and reverse, GTG ATG GCA TGG ACT GTG GT. The PCR products were stained with Loading Star (Dynebio co., Ltd., Seongnam-si, Korea) and electrophoresed on a $1 \%$ agarose gel. The bands were detected by a UV transilluminator (Core Bio, La Jolla, CA, USA).

Western blot analysis. HMC-1 $\left(2 \times 10^{6}\right.$ cells/well) were seeded in a $60 \Phi$ cell culture dish and starved with serum-free IMDM for $6 \mathrm{~h}$. After starvation, cells were pretreated with genistein for $30 \mathrm{~min}$, and stimulated with $20 \mathrm{nmol} / 1 \mathrm{PMA}$ and $1 \mu \mathrm{mol} / 1$ of the calcium ionophore, A23187, for 15, 30 and $60 \mathrm{~min}$. Treated cells were washed with cold phosphate-buffered saline and lysed with modified radioimmunoprecipitation assay buffer [50 mmol/1 Tris-HCl, $0.1 \%$ sodium dodecyl sulfate (SDS), $0.5 \%$ sodium deoxycholate, $1 \% \mathrm{NP}-40$ and $150 \mathrm{mmol} / \mathrm{l}$ sodium chloride $(\mathrm{pH} 8.0)]$ at $4^{\circ} \mathrm{C}$ for $30 \mathrm{~min}$. The lysates were centrifuged at $13,000 \mathrm{x}$ g for $15 \mathrm{~min}$ and the supernatant was used as protein samples. Protein concentration was measured according to the manufacturer's instructions by colorimetric bicinchoninic acid kit (Thermo Scientific, Pittsburgh, PA, USA). Equivalent amounts of protein were separated by $10 \%$ SDS-polyacrylamide gel electrophoresis and electrophoretically transferred to polyvinylidene fluoride membrane (Millipore, Billerica, MA, USA). The membranes were incubated with blocking solution (5\% skimmed milk in Tris-buffered saline TBS) for $1 \mathrm{~h}$. Following blocking, membranes were probed with anti-ERK (sc-292838), anti-p-ERK (sc-7383), anti-p38 (sc-535) and anti-p-p38 (sc-7973) primary antibodies (Santa Cruz Biotechnology, Inc., Santa Cruz, CA, USA), and with horseradish peroxidase (HRP)-conjugated anti-rabbit or anti-mouse secondary antibodies (Santa Cruz Biotechnology) for $2 \mathrm{~h}$. Bands were visualized using an enhanced chemiluminescence (Bio-Rad Laboratories, Hercules, CA, USA) detection system and exposed to radiographic film.

ELISA. HMC-1 ( $2 \times 10^{4}$ cells/well) were seeded in 96-well U-bottom culture plates. Cells were pretreated with various concentrations of genistein (12.5-50 $\mu \mathrm{mol} / \mathrm{l})$ for $30 \mathrm{~min}$, and stimulated with PMA/A23187 for $48 \mathrm{~h}$. Cultured cells were separated by microcentrifugation and the supernatant was used for samples. IL-6 release was measured by Human 
IL-6 ELISA MAX ${ }^{\mathrm{TM}}$ Deluxe Sets (BioLegend, San Diego, CA, USA), according to the manufacturer's instructions. Briefly, standards and samples were incubated on a capture antibody-coated plate overnight at $4{ }^{\circ} \mathrm{C}$. The detection antibody was added and samples were incubated for $1 \mathrm{~h}$ and avidin-HRP bound to the detection antibody. Substrate solution was added to each well, and the reaction was stopped by addition of a stop solution $\left(2 \mathrm{~N} \mathrm{H}_{2} \mathrm{SO}_{4}\right)$. Absorbance was measured by an ELISA microplate reader at a wavelength of $405 \mathrm{~nm}$.

$\beta$-hexogeminidase assay. HMC-1 $\left(5 \times 10^{5}\right.$ cells/well) were seeded in 24-well plates with IMDM. After a 10-min incubation at $37^{\circ} \mathrm{C}$, cells were pretreated with genistein for $30 \mathrm{~min}$ followed by stimulation with PMA/A23187 for $1 \mathrm{~h}$. Cultured cells were collected by centrifugation $(1,500 \mathrm{x} \mathrm{g})$ for $5 \mathrm{~min}$. The pellet and supernatant were transferred to separate microtubes. The pellet was lysed with $1 \%$ Triton X-100 in Tris-HCl (pH 8.0) for $20 \mathrm{~min}$ at $4^{\circ} \mathrm{C}$. The lysate $(50 \mu \mathrm{l})$ was combined with $50 \mu 12 \mathrm{mM}$ p-nitrophenyl-N-acetyl- $\beta$-D-glucosaminide (Calbiochem, Canada) dissolved in $0.1 \mathrm{~mol} / \mathrm{l}$ citrate buffer $(\mathrm{pH} 4.5)$ for $1 \mathrm{~h}$ at $37^{\circ} \mathrm{C}$. The reaction was ended with $100 \mu \mathrm{l}$ of a stop solution $\left(0.1 \mathrm{~mol} / 1 \mathrm{NaHCO} / \mathrm{Na}_{2} \mathrm{CO}_{3}\right)$, and the absorbance was measured at $405 \mathrm{~nm}$ using an ELISA microplate reader.

Statistical analysis. All the results are expressed as the mean \pm standard deviation of the indicated number of the experiments. Statistical significance was estimated using a Student's t-test for unpaired observations, and the differences were compared with regard to statistical significance by one-way analysis of variance, followed by Bonferroni's post-hoc test. The categorical data from the fertility test were subjected to statistical analysis via the $\chi^{2}$ test.

\section{Results}

Genistein had no effect on cytotoxicity in a human mast cell line $(H M C-1)$. In an initial series of experiments, whether genistein influenced the cytotoxicity of a human mast cell line (HMC-1) was investigated. HMC-1 cells were treated with various concentrations of genistein, ranging from 0 to $50 \mu \mathrm{M}$, for $24 \mathrm{~h}$ and subjected to an MTT assay. As shown in Fig. 1B, the addition of $50 \mu \mathrm{M}$ genistein did not alter HMC-1 numbers when compared to the control or cells treated with only medium [DMSO $(0.02 \%)$ in IMDM]. Therefore, this range of genistein concentrations was used to determine the anti-inflammatory effects of genistein during mast cell activation.

Genistein suppresses the expression levels of pro-inflammatory cytokines in PMA/A23187-induced HMC-1. Pro-inflammatory cytokines are important mediators of inflammation, cell recruitment and allergenic responses (22). To evaluate the effect of genistein on the gene expression of pro-inflammatory cytokines, HMC-1 was initially treated with genistein and the cells were stimulated with PMA $(20 \mathrm{nM})$ and A23187 $(1 \mu \mathrm{M})$, prior to analyzing the gene expression of the pro-inflammatory cytokines using RT-PCR. As shown in Fig. 2A, a high level of genistein $(50 \mu \mathrm{M})$ significantly suppressed the gene expression of IL-1 $\beta$ and IL- 6 . However, TNF- $\alpha$ gene expression remained unaltered (Fig. 2B).<smiles>O=c1c(-c2ccc(O)cc2)coc2cc(O)cc(O)c12</smiles>

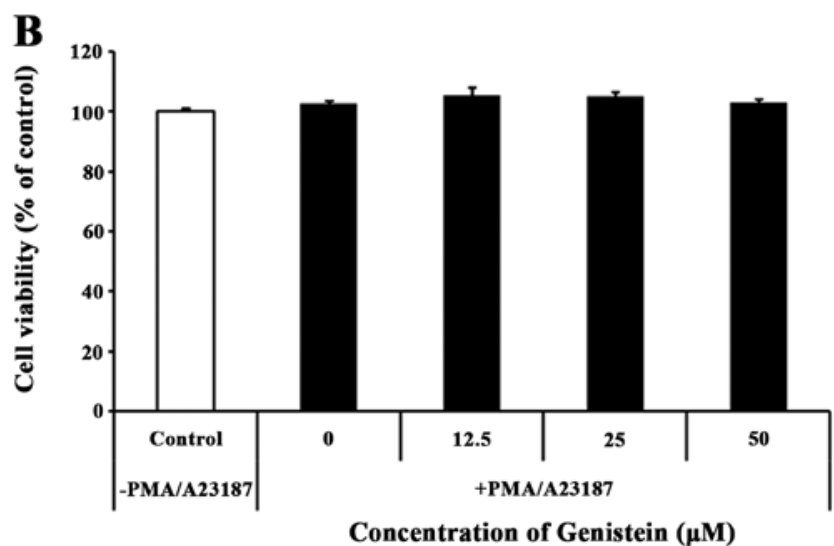

Figure 1. Cytotoxicity of genistein on HMC-1. (A) The chemical structure of genistein. HMC-1 $\left(2 \times 10^{4}\right.$ cells/well) were pretreated with genistein $(12.5-50 \mu \mathrm{M})$ and incubated for $24 \mathrm{~h}$. (B) Cell viability was determined by MTT assay. Data are representative of three independent experiments. Each datum represents the means $\pm \mathrm{SD}$ of three independent experiments.

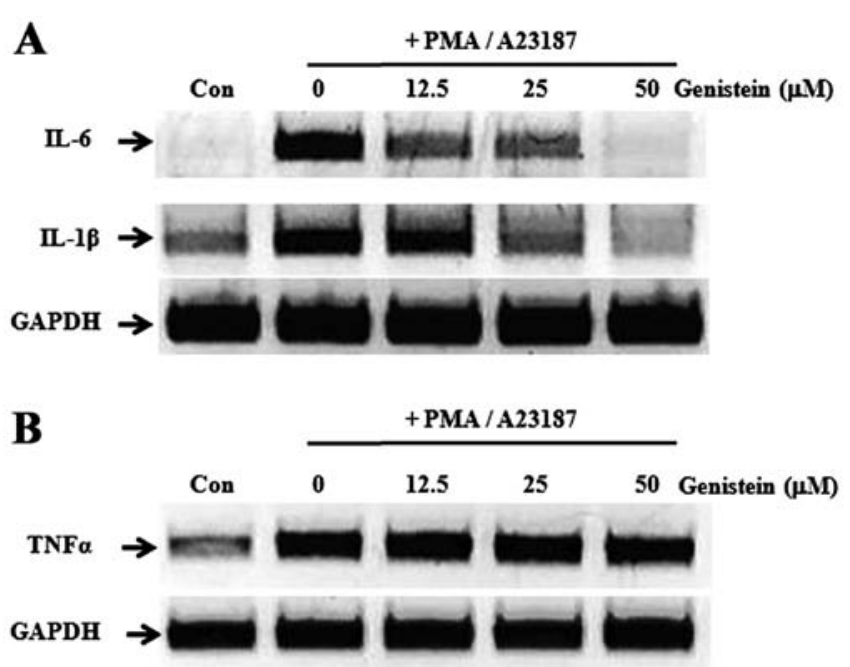

Figure 2. Effect of genistein on gene expression of inflammatory cytokines in activated HMC-1. HMC-1 $\left(5 \times 10^{6}\right.$ cells/well) were pretreated with various concentrations of genistein (12.5-50 $\mu \mathrm{M})$ for $30 \mathrm{~min}$ and stimulated by PMA $(20 \mathrm{nM})$ and $\mathrm{A} 23187(1 \mu \mathrm{M})$ for $2 \mathrm{~h}$. Total RNA was extracted and gene expression of (A) IL-1 $\beta$, IL- 6 and (B) TNF- $\alpha$ was quantified by RT-PCR. Products were electrophoresed on a $1 \%$ agarose gel, stained with ethidium bromide, and captured using a Kodak DC 290 digital camera. Data are representative of three independent experiments. PMA, phorbol 12-myristate 13-acetate; IL, interleukin; TNF- $\alpha$, tumor necrosis factor- $\alpha$; RT-PCR, reverse transcription polymerase chain reaction.

Genistein significantly inhibits IL-6 production in PMA/A23187-induced HMC-1. IL-6 is crucial for mast cell maturation; activated mast cells increase IL-6 mRNA associated with protein kinase $\mathrm{C}$ (PKC) activity and also upregulate histamine production (23). We found that genistein suppressed gene expression of pro-inflammatory cytokines IL-1 $\beta$ and 


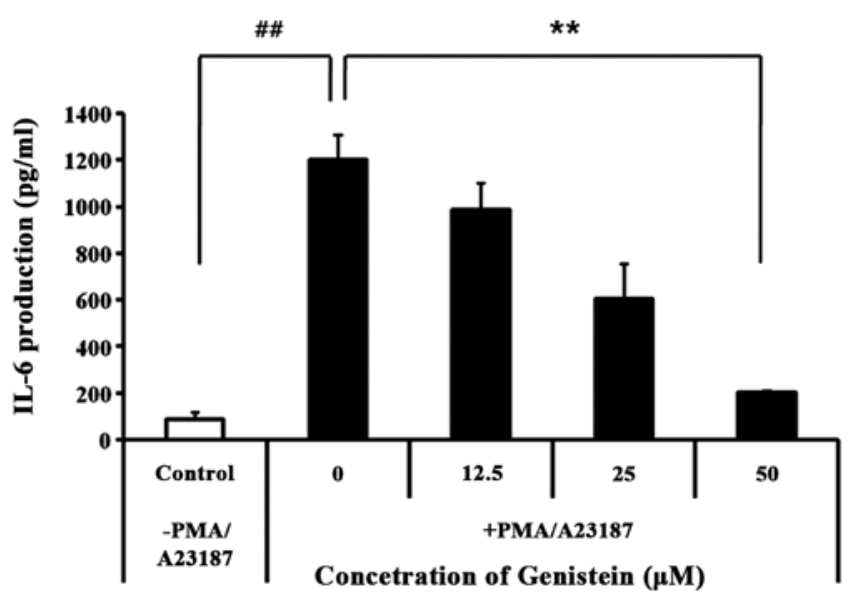

Figure 3. Effect of genistein on production of IL-6 in activated HMC-1. HMC-1 $\left(1 \times 10^{6}\right.$ cells/well) were pretreated with genistein for $30 \mathrm{~min}$, stimulated with PMA $(20 \mathrm{nM})$ and A23187 $(1 \mu \mathrm{M})$ for $48 \mathrm{~h}$. IL-6 levels in the supernatant were measured using ELISA and represented as the means \pm SD of three independent experiments. ${ }^{\#} \mathrm{P}<0.01$ vs. unstimulated mast cells (control, medium only); ${ }^{* *} \mathrm{P}<0.01$ vs. PMA/A23187-stimulated mast cells. IL, interleukin; PMA, phorbol 12-myristate 13-acetate.

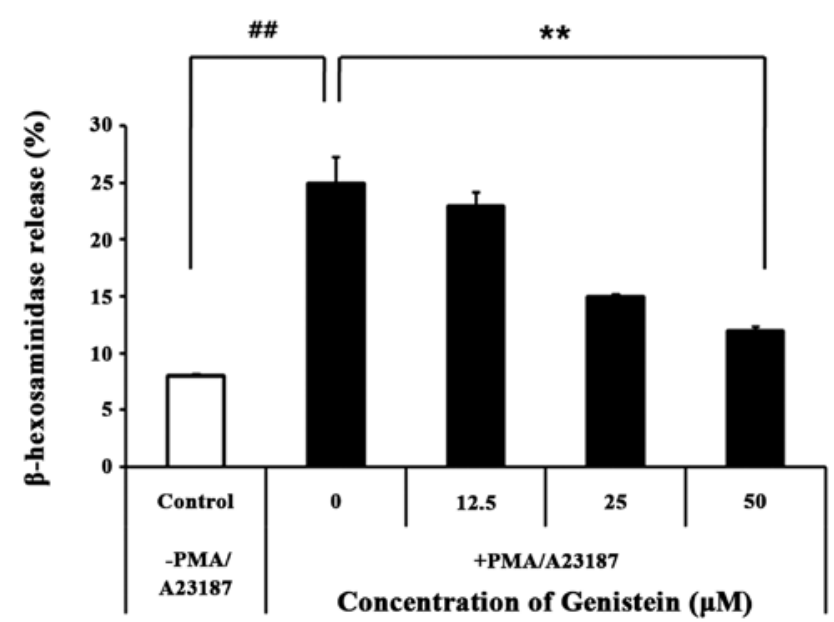

Figure 4. Effect of genistein on $\beta$-hexosaminidase in activated HMC-1. HMC-1 $\left(5 \times 10^{6}\right.$ cells/well) were pretreated with various concentrations of genistein $(12.5-50 \mu \mathrm{M})$ for 30 min and stimulated by PMA (20 $\mathrm{nM})$ and A23187 $(1 \mu \mathrm{M})$ for $1 \mathrm{~h}$. The level of degranulation was assessed from the activity of $\beta$-hexosaminidase in the culture supernatant and plotted as the percent release. ${ }^{\# \#} \mathrm{P}<0.01$ vs. unstimulated mast cells (control, medium only); ${ }^{* *} \mathrm{P}<0.01$ vs. PMA/A23187-stimulated mast cells. PMA, phorbol 12-myristate 13-acetate.

IL-6 (Fig. 2A). To confirm the effect of genistein on the gene expression of pro-inflammatory cytokines, culture supernatants were assayed for cytokine levels by ELISA. HMC-1 cells were pretreated with genistein $(12.5-50 \mu \mathrm{M})$ for $30 \mathrm{~min}$, and subsequently stimulated with PMA and A23187 for $48 \mathrm{~h}$. As shown in Fig. 3, genistein strongly decreased the production of IL-6 in PMA/A23187-induced HMC-1. These results indicate that genistein inhibits pro-inflammatory cytokines, such as IL-1 $\beta$ and IL-6 in PMA/A23187-activated HMC-1.

Genistein inhibits histamine release in PMA/A23187-induced $H M C$ - 1 . In order to determine the effect of genistein on mast

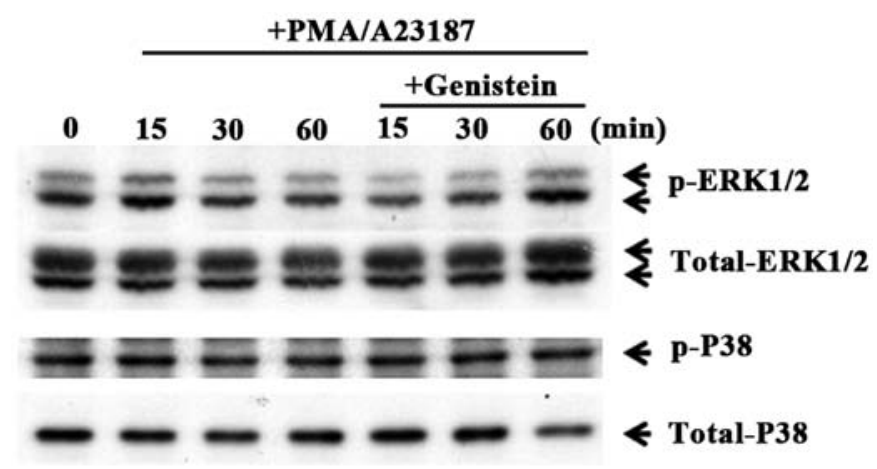

Figure 5. Effect of genistein on MAPK phosphorylation in activated HMC-1. Cells were treated with $50 \mu \mathrm{M}$ genistein for 15,30 and $60 \mathrm{~min}$. Cell lysates were prepared and blotted with anti-phospho-ERK1/2, anti-ERK1/2, anti-phospho-p38 and anti-p38 antibodies. Nuclear extracts were blotted with anti-phospho-p65 antibody. A signal was detected with biotinylated goat anti-rabbit IgG and visualized using enhanced chemiluminescence. The results are representative of four experiments. MAPK, mitogen-activated protein kinase; ERK, extracellular signal-regulated kinase; IgG, immunoglobulin G.

cells degranulation, the effect of genistein was investigated on the release of $\beta$-hexosaminidase, a secretory granule marker that is released in parallel with histamine. As shown in Fig. 4, $50 \mu \mathrm{M}$ genistein reduced $\beta$-hexosaminidase release by 2 -fold, indicating that genistein inhibits mast cell degranulation.

Genistein regulates phosphorylation of ERK. To evaluate the mechanism of the effect of genistein on gene expression of pro-inflammatory cytokines, the influence of genistein on MAPK phosphorylation was investigated. IL-1 $\beta$ and IL-6 expression is regulated by a transcription factor, $\mathrm{NF}-\kappa \mathrm{B}$, and activated by MAPK pathways (24). In order to investigate the effects of genistein on the MAPK signaling pathways, HMC-1 cells were pretreated with $50 \mu \mathrm{M}$ genistein and kinase activation was assessed. Phosphorylation of p38 MAPK and ERK1/2 were measured by phosphor-specific western blotting. As shown in Fig. 5, genistein inhibited the phosphorylation of ERK1/2 in PMA/A23187-induced mast cells. These results indicate that genistein inhibits pro-inflammatory cytokine production via regulation of the ERK pathways.

\section{Discussion}

Allergic diseases, including asthma and anaphylaxis, are a severe health burden for a number of nations. In the United States, an estimated 20 million patients are treated for allergic diseases, at an annual cost exceeding \$15 billion (25). Anaphylaxis is a type I hypersensitivity reaction mediated by IgE-activated mast cells and occurs locally and systemically; it is caused by various inflammatory mediators, such as histamine, tryptase and several cytokines from activated mast cells. These inflammatory mediators affect leukocyte recruitment, and cause vasodilation, increased vascular permeability and bronchial-constriction (26). Therefore, numerous investigators have sought to develop novel therapeutic adjuvants for allergenic inflammation via regulation of mast cells. To address this, the anti-inflammatory effects of genistein, a phytoestrogen, were investigated on mast cell activation. 
In general, PMA activates $\mathrm{PKC}$, resulting in activation of mast cells. In addition, the calcium ionophore, A23187, increases the permeability of the cell membrane to $\mathrm{Ca}^{2+}$ and can selectively activate gene expression of calcium-regulated genes (27). In addition, A23187 alone has been shown to induce granule release in mast cells (8). The present study assessed HMC-1, an immature human mast cell line derived from the peripheral blood of a patient suffering from mast cell leukemia. HMC-1 lacks FceRI, making it difficult to activate the mast cells through IgE-mediated responses. In addition, co-treatment with PMA and A23187 was also used to activate mast cells.

Genistein is a phytoestrogen isolated from Genista tinctoria; the chemical name is derived from the generic name.Kimetal(28) reported that genistein-4'-O- $\alpha$-L-rhamnopyranosyl- $(1 \rightarrow 2)$ $\beta$-D-glucopyranoside from Sophora japonica (Leguminosae) ameliorates mast cell-mediated allergic inflammation in vivo and in vitro. In addition, the study by Kim et al indicates that the anti-inflammatory effect of the genistein compound is involved in the regulation of inflammatory cytokines, including IL-8 and TNF $\alpha$. A recent study found that genistein inhibited transcription factors, including GATA-binding protein-3 and signal transducer and activator of transcription- 6 , which control the Th1/Th2 response in an asthma mouse model. Specifically, genistein decreased Th2-type cytokine levels and attenuated ovalbumin-induced airway inflammation (29). However, the underlying mechanisms by which genistein inhibits inflammatory mediators in mast cell activation remain unknown.

To the best of our knowledge, this is the first study showing that genistein inhibits pro-inflammatory cytokines in activated mast cells. Genistein was found to significantly suppress IL-1 $\beta$ and IL-6 expression in PMA/A23187-induced mast cells (Fig. 2A). In general, mast cells release an array of mediators with the potential to cause allergic inflammation, such as the pro-inflammatory cytokines, IL-1 $\beta$, IL-6 and TNF- $\alpha$. Specifically, IL-1 $\beta$ plays an important role in allergic response; the local accumulation of IL- 6 is associated with a local allergic reaction, and IL- $1 \beta$ and IL- 6 promote inflammation and a mast cell-mediated immune response (30-32). These studies indicate that reduction of pro-inflammatory cytokines from mast cells is one of the keys to reducing inflammatory symptoms. The results of the present study, showing inhibition of IL-1 $\beta$ and IL- 6 expression by genistein, support the idea that genistein has an anti-inflammatory effect resulting from the reduction of these mediators in mast cells. Additionally, the induction of these cytokines was involved in the activation of the MAPK and NF- $\mathrm{NB}$ pathway. The study by Blackwell et al (33) reported on the role of $N F-\kappa B$ activation in the regulation of cytokine production in allergic inflammation, and showed that $\mathrm{NF}-\kappa \mathrm{B}$ activation is also associated with MAPK activation. To address this, the inhibitory effect of genistein was investigated on pro-inflammatory cytokines via regulation of MAPK activation. Genistein inhibited the phosphorylation of ERK. However, p38 MAPK levels were not altered by pretreatment with genistein in activated mast cells (Fig. 5). These results indicate that the inhibitory effect of genistein on pro-inflammatory cytokine production is associated with ERK signaling pathways.

In conclusion, genistein inhibits the gene expression and production of pro-inflammatory cytokines IL-1 $\beta$ and IL-6, but does not alter TNF- $\alpha$ levels. Additionally, genistein attenuates activation of the ERK signaling pathway. The present study also indicates that genistein has potential for use as a treatment for allergic inflammation and anaphylactic shock.

\section{Acknowledgements}

The present study was financially supported by the Ministry of Education, Science Technology (MEST) and National Research Foundation of Korea (NRF) through the Human Resource Training Project for Regional Innovation (2011-04-Dae-05016) and the Leading Foreign Research Institute Recruitment Program through the National Research Foundation of Korea (NRF) funded by the Ministry of Education, Science and Technology (MEST) (2011-0030034).

\section{References}

1. Metcalfe DD, Peavy RD and Gilfillan AM: Mechanisms of mast cell signaling in anaphylaxis. J Allergy Clin Immunol 124: 639-646, 2009.

2. Oskeritzian CA, Price MM, Hait NC, et al: Essential roles of sphingosine-1-phosphate receptor 2 in human mast cell activation, anaphylaxis, and pulmonary edema. J Exp Med 207: 465-474, 2010.

3. Worm M: Epidemiology of anaphylaxis. Chem Immunol Allergy 95: 12-21, 2010.

4. Boden SR and Wesley Burks A: Anaphylaxis: a history with emphasis on food allergy. Immunol Rev 242: 247-257, 2011.

5. Lee JK and Vadas P: Anaphylaxis: mechanisms and management. Clin Exp Allergy 41: 923-938, 2011.

6. Simons FE: World Allergy Organization survey on global availability of essentials for the assessment and management of anaphylaxis by allergy-immunology specialists in health care settings. Ann Allergy Asthma Immunol 104: 405-412, 2010.

7. Simons FE: Anaphylaxis: recent advances in assessment and treatment. J Allergy Clin Immunol 124: 625-636, 2009.

8. Zhang B, Alysandratos KD, Angelidou A, et al: Human mast cell degranulation and preformed TNF secretion require mitochondrial translocation to exocytosis sites: relevance to atopic dermatitis. J Allergy Clin Immunol 127: 1522-1531, 2011.

9. Tchougounova E, Pejler G and Abrink M: The chymase, mouse mast cell protease 4 , constitutes the major chymotrypsin-like activity in peritoneum and ear tissue. A role for mouse mast cell protease 4 in thrombin regulation and fibronectin turnover. J Exp Med 198: 423-431, 2003.

10. Lee S, Park HH, Son HY, et al: DA-9601 inhibits activation of the human mast cell line HMC-1 through inhibition of NF- $\kappa$ B. Cell Biol Toxicol 23: 105-112, 2007.

11. Shin J, Pan H and Zhong XP: Regulation of mast cell survival and function by tuberous sclerosis complex 1. Blood 119: 3306-3314, 2012.

12. Kalesnikoff $\mathbf{J}$ and Galli SJ: New developments in mast cell biology. Nat Immunol 9: 1215-1223, 2008.

13. Guma M, Kashiwakura J, Crain B, et al: JNK1 controls mast cell degranulation and IL-1 $\beta$ production in inflammatory arthritis. Proc Natl Acad Sci USA 107: 22122-22127, 2010.

14. Lu Y, Piao D, Zhang H, et al: Saucerneol F inhibits tumor necrosis factor- $\alpha$ and IL- 6 production by suppressing Fyn-mediated pathways in FceRI-mediated mast cells. Food Chem Toxicol 59: 696-702, 2013

15. Lee J and Lim KT: Expression of TNF- $\alpha$ and IL-6 in HMC-1 cells treated with bisphenol $\mathrm{A}$ is attenuated by plant-originating glycoprotein $(75 \mathrm{kDa})$ by blocking p38 MAPK. Naunyn Schmiedebergs Arch Pharmacol 382: 51-61, 2010.

16. Masilamani M, Wei J, Bhatt S, Paul M, Yakir S and Sampson HA: Soybean isoflavones regulate dendritic cell function and suppress allergic sensitization to peanut. J Allergy Clin Immunol 128: 1242-1250, 2011.

17. Dixon RA and Ferreira D: Genistein. Phytochemistry 60: 205-211, 2002.

18. Kitaura J, Asai K, Maeda-Yamamoto M, Kawakami Y,Kikkawa U and Kawakami T: Akt-dependent cytokine production in mast cells. J Exp Med 192: 729-740, 2000. 
19. Frey RS and Singletary KW: Genistein activates p38 mitogen-activated protein kinase, inactivates ERK1/ERK2 and decreases $\mathrm{Cdc} 25 \mathrm{C}$ expression in immortalized human mammary epithelial cells. J Nutr 133: 226-231, 2003.

20. Zhao JH, Arao Y, Sun SJ, Kikuchi A and Kayama F: Oral administration of soy-derived genistin suppresses lipopolysaccharide-induced acute liver inflammation but does not induce thymic atrophy in the rat. Life Sci 78: 812-819, 2006.

21. Palanisamy N, Kannappan S and Anuradha CV: Genistein modulates NF- $\kappa \mathrm{B}$-associated renal inflammation, fibrosis and podocyte abnormalities in fructose-fed rats. Eur J Pharmacol 667: 355-364, 2011.

22. Woolley DE and Tetlow LC: Mast cell activation and its relation to proinflammatory cytokine production in the rheumatoid lesion. Arthritis Res 2: 65-74, 2000.

23. Conti P, Kempuraj D, Di Gioacchino M, et al: Interleukin-6 and mast cells. Allergy Asthma Proc 23: 331-335, 2002.

24. de Bittencourt Pasquali MA, Gelain DP, Zeidan-Chulia F, et al: Vitamin A (retinol) downregulates the receptor for advanced glycation endproducts (RAGE) by oxidant-dependent activation of p38 MAPK and NF- $\kappa$ B in human lung cancer A549 cells. Cell Signal 25: 939-954, 2013.

25. Pullen NA, Barnstein BO, Falanga YT, et al: Novel mechanism for FceRI-mediated signal transducer and activator of transcription 5 (STAT5) tyrosine phosphorylation and the selective influence of STAT5B over mast cell cytokine production. J Biol Chem 287: 2045-2054, 2012.

26. Galli SJ, Tsai M and Piliponsky AM: The development of allergic inflammation. Nature 454: 445-454, 2008.
27. Resendez E Jr, Ting J, Kim KS, Wooden SK and Lee AS: Calcium ionophore A23187 as a regulator of gene expression in mammalian cells. J Cell Biol 103: 2145-2152, 1986.

28. Kim SJ, Kim YJ, Lee JH, et al: Genistein-4'-O- $\alpha$-L-rhamnop yranosyl-(1 $\rightarrow 2)-\beta$-D-glucopyranoside from Sophora japonica (Leguminosae) ameliorates mast cell-mediated allergic inflammation in vivo and in vitro. Orient Pharm Exp Med 11: 207-213, 2011.

29. Gao F, Wei D, Bian T, et al: Genistein attenuated allergic airway inflammation by modulating the transcription factors T-bet, GATA-3 and STAT-6 in a murine model of asthma. Pharmacology 89: 229-236, 2012.

30. Yu SC and Li XY: Effect of ginsenoside on IL-1 $\beta$ and IL-6 mRNA expression in hippocampal neurons in chronic inflammation model of aged rats. Acta Pharmacol Sin 21: 915-918, 2000.

31. Ganeshan K, Johnston LK and Bryce PJ: TGF- $\beta 1$ limits the onset of innate lung inflammation by promoting mast cell-derived IL-6. J Immunol 190: 5731-5738, 2013.

32. Ganeshan $\mathrm{K}$ and Bryce PJ: Regulatory $\mathrm{T}$ cells enhance mast cell production of IL-6 via surface-bound TGF- $\beta$. J Immunol 188: 594-603, 2012.

33. Blackwell TS, Blackwell TR and Christman JW: Impaired activation of nuclear factor-kappaB in endotoxin-tolerant rats is associated with down-regulation of chemokine gene expression and inhibition of neutrophilic lung inflammation. J Immunol 158: 5934-5940, 1997. 